\title{
Feingold syndrome
}

INSERM

\section{Source}

INSERM. (1999). Orphanet: an online rare disease and orphan drug data base. Feingold syndrome. ORPHA:1305

Feingold syndrome (FS), also known as oculo-digito-esophageal-duodenal (ODED) syndrome, is a rare inherited malformation syndrome characterized by microcephaly, short stature and numerous digital anomalies and is comprised of two subtypes: FS type 1 (FS1) and FS type 2 (FS2) (see these terms). FS1 is by far the most common form while FS2 has only been reported in 3 patients and has the same clinical characteristics as FS1, apart from the absence of gastrointestinal atresia and short palpebral fissures. 